\title{
Ascending cholangitis after successful surgical repair of biliary atresia
}

\author{
AKIO KOBAYASHI, TAKEKO UTSUNOMIYA, YOSHIRO OHBE, and \\ KOHICHI SHIMIZU \\ From the Department of Paediatrics and Department of Pathology, National Children's Hospital, Tokyo, Japan
}

\begin{abstract}
Kobayashi, A., Utsunomiya, T., Ohbe, Y., and Shimizu, K. (1973). Archives of Disease in Childhood, 48,697. Ascending cholangitis after successful surgical repair of biliary atresia. Since the introduction of hepatic porto-enterostomy, encouraging results have been obtained in treating extrahepatic biliary atresia, particularly in the case of infants with atresia or agenesis of the extrahepatic ducts, who would not previously have been considered amenable to surgery.

Out of 17 successfully repaired cases who had shown good bile excretion after surgery and who had no jaundice, $8(47 \%)$ developed ascending cholangitis $3 \frac{1}{2}$ to $8 \frac{1}{2}$ months after surgery.

Cholangitis of this type formed a recognizable picture, with repeated attacks of fever, reappearance of obstructive jaundice, raised erythrocyte sedimentation rate, leucocytosis with shift to the left, and anaemia. The condition was often resistant to antibiotic therapy, and was fatal in 3 cases.
\end{abstract}

Although some 4 to $18 \%$ of cases of congenital biliary atresia have been considered amenable to surgery (Holmes, 1916; Gerrish and Cole, 1951; Gross, 1953; Silverberg, Craig, and Gellis, 1960), the percentage of cases successfully repaired is much smaller (Gross, 1953; Moore, 1953). In the so-called surgically 'incorrectable' cases of biliary atresia, surgical intervention to establish bile drainage from liver to intestine has, until recently, been unsuccessful (Longmire and Sanford, 1948, 1949; Sterling, 1957; Sterling and Lowenburg, 1962). Recently more encouraging results have been reported by a few authors (Kasai et al., 1963, 1968; Sawaguchi et al., 1971, 1972), employing the operation of hepatic porto-enterostomy, first described by Longmire and Sanford (1948), and later by Redo (1954) and Kasai et al. $(1963,1968)$. Kasai et al. (1968) reported that 19 out of 53 cases showed good or fairly good excretion of bile after surgery, with complete cure in 6 . Sawaguchi et al. $(1971,1972)$ reported similar results. However, about half of the cases who had shown initially good bile excretion developed ascending cholangitis several months after surgery. The condition was often resistant to antibiotic therapy, and was sometimes fatal. The purpose of this paper is to describe the clinical features of the condition in more detail.

Received 1 February 1973.

\section{Patients}

From January 1967 to June 1972, 55 patients (35 females, 20 males) were admitted with the diagnosis of biliary atresia to the Department of Paediatrics, National Children's Hospital of Tokyo. The diagnosis was confirmed by laparotomy, when an operative cholangiogram was also carried out. Among these only $3(6 \%)$ were of the so-called surgically 'correctable' type, the remaining $52(95 \%)$ being of the surgically 'incorrectable' type. In the incorrectable cases the proximal hepatic ducts are absent or rudimentary, making it impossible to anastomose any portion of the extrahepatic ducts to the gastrointestinal tract.

Operation performed in all these incorrectable cases was hepatic portojejunostomy, as described by Kasai $e t$ al. (1968) and Sawaguchi et al. (1971, 1972). Two correctable cases were treated with hepaticojejunostomy and the other with choledochojejunostomy in Roux-en-Y fashion. Two methods were used to establish hepatic portojejunostomy: a one-stage and a two-stage method. The former, as described by Kasai et al. (1968), was performed by Roux-en-Y anastomosis and carried out in 12 cases in the present series; the two-stage method, devised by Sawaguchi et al. (1971) and shown schematically in the Fig., was performed in 40 cases.

In 13 patients out of $55(24 \%)$ good bile excretion was observed after surgery and jaundice disappeared; 3 were the correctable type, and 10 were the incorrectable type (3, one-stage method; 7 , two-stage method).

In addition, 4 cases that had been admitted with the diagnosis of biliary atresia to this hospital and had been 


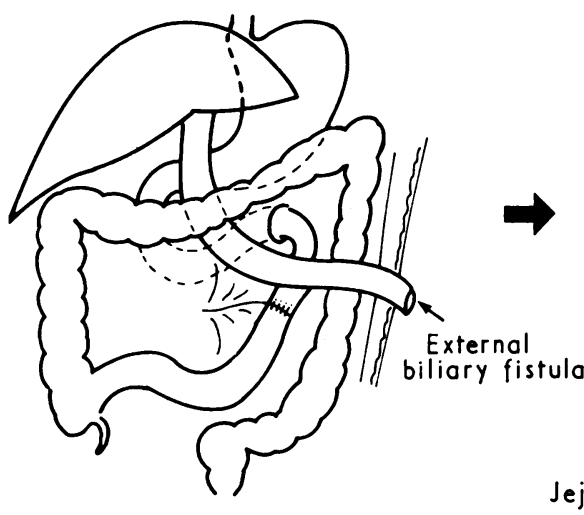

$a$

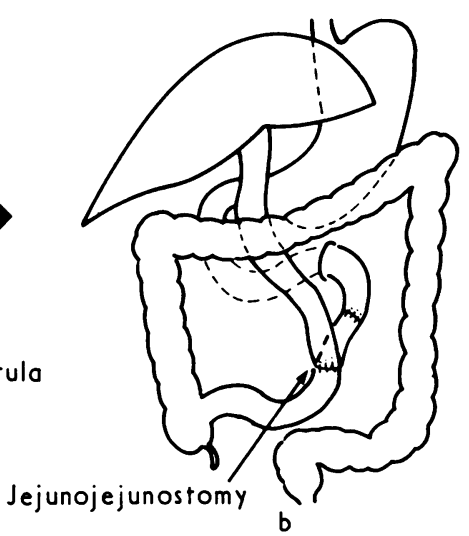

(a) First procedure, (b) second procedure. successfully repaired by hepatic portojejunostomy for the incorrectable type were referred for medical follow-up from the Department of Surgery. 3 of these 4 patients had had a two-stage procedure, and the other a one-stage procedure.

The age of the patients at operation ranged from 4 weeks to $3 \frac{1}{2}$ months with an average of 2.3 months in 17 successfully repaired cases, and from 6 weeks to $7 \frac{1}{2}$ months with an average of 3.5 months in 42 uncorrected cases.

At a time varying from $3 \frac{1}{2}$ to $8 \frac{1}{2}$ months after operation 8 of the 17 patients became ill with attacks of remittent fever, reappearance of obstructive jaundice, abdominal distension, raised erythrocyte sedimentation rate (ESR), leucocytosis with shift to the left, and anaemia. There was no evidence of respiratory infection, urinary tract infection, or septicaemia. Necropsy examination of 2 of the patients who had shown these signs and symptoms revealed bacterial cholangitis and multiple cholangitic abscesses. Organisms grown from the abscesses were intestinal flora. We concluded that ascending cholangitis was also responsible for the illness characterized by the above signs and symptoms in our other patients. The 8 cases in whom this diagnosis was made are briefly described.

\section{Case reports}

Case 1. A male infant aged 3 months was admitted with the diagnosis of biliary atresia. Laparotomy at $3 \frac{1}{2}$ months revealed a small gallbladder and rudimentary hepatic and common duct. One-stage hepatic portojejunostomy was performed leaving a segment of the jejunum for bile drainage about $50 \mathrm{~cm}$ long. Bile excretion was good, resulting in disappearance of jaundice by the age of 6 months.

Six months after operation he developed high fever and obstructive jaundice, and was readmitted to the hospital. He showed pallor, marked abdominal distension, hepatosplenomegaly, and engorgement of the superficial veins of the abdominal wall. Laboratory findings at this stage are shown in Table I. A diagnosis of ascending cholangitis was made and antibiotic therapy was instituted using gentamicin, kanamycin, chloramphenicol, ampicillin, carbenicillin, lincomycin, and cephaloridine. The disease deteriorated progressively, jaundice deepened, and, in addition, ascites devaloped.

Laboratory data of 8 cases of cholangitis

\begin{tabular}{|c|c|c|c|c|c|c|c|c|c|c|}
\hline \multirow{2}{*}{$\begin{array}{c}\text { Case } \\
\text { no. }\end{array}$} & \multirow{2}{*}{$\begin{array}{c}\mathbf{H b} \\
(\mathrm{g} / 100 \mathrm{ml})\end{array}$} & \multicolumn{3}{|c|}{ White blood cells } & \multirow{2}{*}{$\underset{(\mathrm{mm} / \mathrm{hr})}{\mathrm{ESR}}$} & \multirow{2}{*}{ CRP } & \multirow{2}{*}{$\mathrm{CCF}$} & \multirow{2}{*}{$\begin{array}{c}\text { TTT } \\
\text { (unit) }\end{array}$} & \multirow{2}{*}{$\underset{\text { (unit) }}{\text { ZnS }}$} & \multirow{2}{*}{$\begin{array}{c}\text { Bilirubiæu } \\
\text { total/dirêt } \\
\text { (mg/100 }\end{array}$} \\
\hline & & $\begin{array}{c}\text { Count } \\
\left(\text { per } \mathrm{mm}^{3} \text { ) }\right.\end{array}$ & $\begin{array}{c}\text { Band forms } \\
(\%)\end{array}$ & $\begin{array}{l}\text { Polymorphs } \\
(\%)\end{array}$ & & & & & & \\
\hline $\begin{array}{l}1 \\
2 \\
3 \\
4 \\
5 \\
6 \\
7 \\
8\end{array}$ & $\begin{array}{r}9 \cdot 3 \\
10 \cdot 9 \\
7 \cdot 7 \\
9 \cdot 9 \\
9 \cdot 0 \\
10 \cdot 6 \\
8 \cdot 9 \\
7 \cdot 3\end{array}$ & $\begin{array}{r}15,300 \\
15,800 \\
13,900 \\
14,000 \\
12,100 \\
13,500 \\
13,000 \\
7,200\end{array}$ & $\begin{array}{l}23 \\
26 \\
26 \\
15 \\
12 \\
\\
30\end{array}$ & $\begin{array}{l}36 \\
26 \\
28 \\
21 \\
12 \\
\\
19\end{array}$ & $\begin{array}{r}143 \\
59 \\
112 \\
122 \\
151 \\
77 \\
38 \\
23\end{array}$ & $\begin{array}{l}5+ \\
2+ \\
5+ \\
3+ \\
1+ \\
4+ \\
3+\end{array}$ & $\begin{array}{l}2+ \\
4+ \\
2+ \\
-3+ \\
2+\end{array}$ & $\begin{array}{r}38 \cdot 4 \\
7 \cdot 0 \\
14 \cdot 5 \\
10 \cdot 9 \\
17 \cdot 4 \\
31 \cdot 5 \\
12 \cdot 5 \\
8 \cdot 0\end{array}$ & $\begin{array}{r}33 \cdot 9 \\
8 \cdot 4 \\
35 \cdot 7 \\
13 \cdot 3 \\
27 \cdot 0 \\
28 \cdot 5 \\
8 \cdot 6 \\
4 \cdot 7\end{array}$ & $\begin{array}{l}6 \cdot 9 / 4 \cdot \frac{3}{3} \\
8 \cdot 4 / 5 \cdot \frac{8}{2} \\
5 \cdot 7 / 4 \cdot 3 \\
4 \cdot 9 / 3 \cdot 5 \\
2 \cdot 5 / 1 \cdot \frac{5}{2} \\
2 \cdot 5 / 2 \cdot 1 \\
9 \cdot 9 / 7 \cdot 1 \\
4 \cdot 9 / 4 \cdot 5\end{array}$ \\
\hline
\end{tabular}

${ }^{\star}$ K-K unit, Kind-King unit. CRP, C-reactive protein; CCF, cephalin-cholesterol flocculation; TTT, thymol turbidity test;ZnS, zinc sulphate ${ }^{\prime}$ st 


\section{Ascending cholangitis after successful surgical repair of biliary atresia}

Laboratory studies at 14 months of age showed $\mathrm{Hb}$ $8.6 \mathrm{~g} / 100 \mathrm{ml}$, ESR $149 \mathrm{~mm} / \mathrm{hr}$, total serum protein 8.0 $\mathrm{g} / 100 \mathrm{ml}$ with $1.8 \mathrm{~g} / 100 \mathrm{ml}$ albumin and $6 \cdot 2 \mathrm{~g} / 100 \mathrm{ml}$ globulin, cephalin-cholesterol flocculation $3+$, thymol turbidity 20.0 units, and zinc sulphate 42.8 units. Serum total cholesterol was $51 \mathrm{mg} / 100 \mathrm{ml}$, serum total bilirubin $15.0 \mathrm{mg} / 100 \mathrm{ml}$, SGOT 56 units, and SGPT 28 units.

Blood transfusion, intravenous plasma preparation, diuretics, and intramuscular vitamin $K_{1}$ were given, but despite the intensive therapy the patient died at the age of 15 months.

At necropsy the abdominal cavity contained about 500 ml ascitic fluid. Pus of pale greenish-yellow colour filled dilated intrahepatic bile ducts. The liver contained small multiple abscesses. Varices were present in the submucosa of the lower oesophagus. The heart was hypertrophied. Culture of hepatic abscesses revealed Esch. coli +++ , klebsiella ++ , Proteus mirabilis + , and Streptococcus mucosus + .

Case 2. A female infant was admitted with jaundice and clay-coloured stools at the age of $1 \frac{1}{2}$ months. Laparotomy at 2 months of age revealed that the hepatic ducts were rudimentary and the gallbladder small. The proximal choledochus was cystic. One-stage operation of hepatic portojejunostomy was performed in a Rouxen-Y fashion, leaving a segment of the jejunum for bile excretion about $50 \mathrm{~cm}$ long. Bile excretion was good, and serum total bilirubin was abruptly reduced from the pre-operative level of $8 \cdot 2$ to $1.45 \mathrm{mg} / 100 \mathrm{ml} 4$ days after operation. Thereafter, her clinical course was uneventful and she was discharged. $8 \frac{1}{2}$ months after operation she developed high fever and obstructive jaundice of moderate degree. The abdomen was prominent with distended superficial veins but no detectable ascites. Laboratory studies at this stage are shown in Table I. Ascending cholangitis was diagnosed and intramuscular and, later, oral chloramphenicol was given. This had an impressive effect; symptoms disappeared, the ESR returned to normal, and CRP became negative. 3 weeks later fever, jaundice, and abdominal distension recurred. Antibiotic therapy was reinstituted, chloramphenicol, gentamicin, carbenicillin, kanamycin, cephaloridine, and ampicillin now had little effect on the disease. She deteriorated progressively, jaundice increased, ascites developed, and she died aged 1 year 11 months.

Necropsy showed multiple small cholangitic abscesses, culture of which gave klebsiella sensitive to chloramphenicol, kanamycin, cephaloridine, and gentamicin.

Case 3. A female infant was admitted at $2 \frac{1}{2}$ months with the diagnosis of biliary atresia. Laparotomy at $3 \frac{1}{2}$ months showed obstruction of the distal choledochus. The hepatic ducts were moderately dilated. A blind common duct was anastomosed to the jejunum in Rouxen-Y fashion. Postoperative course was without incident, bile excretion was fair, and jaundice disappeared completely by 8 months of age.

Seven months after operation fever, abdominal distension, and obstructive jaundice developed. Laboratory findings at this stage are shown in Table I. A diagnosis of ascending cholangitis was made. Antibiotic therapy included gentamicin, chloramphenicol, cephaloridine, and kanamycin. Her condition deteriorated progressively and laboratory studies at 15 months showed serum total bilirubin $17 \cdot 2 \mathrm{mg} / 100 \mathrm{ml}$ (direct bilirubin $12.6 \mathrm{mg} / 100 \mathrm{ml}$ ), SGOT 57 units, SGPT 18 units, serum albumin $1.72 \mathrm{~g} / 100 \mathrm{ml}$, and serum globulin $6 \cdot 22 \mathrm{~g} / 100 \mathrm{ml}$. She died at $18 \mathrm{~m}$ गnths. Necropsy examination was not made.

Case 4. A male infant was admitted at 8 weeks with the diagnosis of biliary atresia. Laparotomy at age 2 months revealed absence of the hepatic ducts; the gallbladder was small and contained only colourless fluid. A small but patent proximal and distal choledochus was found by operative cholangiogram. The two-stage operation of hepatic portojejunostomy was performed. A segment of the jejunum used for bile drainage was about $50 \mathrm{~cm}$ long.

Bile excretion was good after operation. Total serum bilirubin of $13.9 \mathrm{mg} / 100 \mathrm{ml}$ before operation fell to $1 \cdot 27$ $\mathrm{mg} / 100 \mathrm{ml} 3$ months after operation. Other blood chemical findings at this stage were as follows: thymol

after hepatic portojejunostomy

\begin{tabular}{|c|c|c|c|c|c|c|c|c|c|c|}
\hline $\begin{array}{c}\text { Alkaline } \\
\text { phosphatase } \\
\text { (K-K unit) }\end{array}$ & $\begin{array}{l}\text { Cholesterol } \\
(\mathrm{mg} / 100 \mathrm{ml})\end{array}$ & $\begin{array}{c}\text { SGOT } \\
\text { (unit) }\end{array}$ & $\begin{array}{c}\text { SGPT } \\
\text { (unit) }\end{array}$ & $\begin{array}{l}\text { SLDH } \\
\text { (unit) }\end{array}$ & $\begin{array}{c}\text { Serum } \\
\text { protein } \\
(\mathrm{g} / 100 \mathrm{ml})\end{array}$ & $\begin{array}{c}\text { Serum } \\
\text { albumin } \\
(\mathrm{g} / 100 \mathrm{ml})\end{array}$ & $\begin{array}{c}\text { Serum } \\
\gamma-\text { globulin } \\
(\mathrm{g} / 100 \mathrm{ml})\end{array}$ & $\begin{array}{c}\text { Serum } \\
\text { IgG } \\
(\mathrm{mg} / 100 \mathrm{ml})\end{array}$ & $\begin{array}{c}\text { Serum } \\
\text { IgA } \\
(\mathrm{mg} / 100 \mathrm{ml})\end{array}$ & $\begin{array}{c}\text { Serum } \\
\text { IgM } \\
(\mathrm{mg} / 100 \mathrm{ml})\end{array}$ \\
\hline $\begin{array}{l}36 \cdot 8 \\
45 \cdot 8 \\
83 \cdot 4 \\
54 \cdot 7 \\
65 \cdot 0 \\
61 \cdot 0 \\
68 \cdot 0 \\
69 \cdot 5\end{array}$ & $\begin{array}{r}108 \\
119 \\
136 \\
129 \\
148 \\
144 \\
1050 \\
230\end{array}$ & $\begin{array}{r}32 \\
41 \\
92 \\
42 \\
18 \\
47 \\
122 \\
62\end{array}$ & $\begin{array}{r}2 \\
36 \\
46 \\
22 \\
7 \\
16 \\
96 \\
25\end{array}$ & $\begin{array}{l}388 \\
302 \\
254 \\
491 \\
372 \\
400 \\
578\end{array}$ & $\begin{array}{l}7 \cdot 6 \\
5 \cdot 9 \\
8 \cdot 0 \\
6 \cdot 9 \\
9 \cdot 5 \\
7 \cdot 7 \\
9 \cdot 4 \\
6 \cdot 5\end{array}$ & $\begin{array}{l}2 \cdot 1 \\
2 \cdot 3 \\
1 \cdot 6 \\
2 \cdot 7 \\
2 \cdot 4 \\
3 \cdot 1 \\
3 \cdot 7 \\
3 \cdot 8\end{array}$ & $\begin{array}{l}3 \cdot 5 \\
1 \cdot 5 \\
4 \cdot 3 \\
1 \cdot 6 \\
4 \cdot 6 \\
2 \cdot 4 \\
2 \cdot 4 \\
1 \cdot 1\end{array}$ & $\begin{array}{l}2800 \\
1700 \\
\\
1700 \\
2900 \\
1200 \\
2000\end{array}$ & $\begin{array}{l}250 \\
170 \\
\\
190 \\
350 \\
160 \\
250\end{array}$ & $\begin{array}{r}240 \\
28 \\
\\
180 \\
90 \\
210 \\
160\end{array}$ \\
\hline
\end{tabular}


turbidity 0.7 units, zinc sulphate 0.4 units, alkaline phosphatase 22.6 Kind-King units, SGOT 46 units, SGPT 40 units, total cholesterol $100 \mathrm{mg} / 100 \mathrm{ml}$, and total protein $7 \cdot 3 \mathrm{~g} / 100 \mathrm{ml}$.

Four months after the first-stage operation the second operation was performed. Postoperative course was without incident for the next $1 \frac{1}{2}$ months, but fever then appeared with mild jaundice and abdominal distension. Laboratory data at this stage are shown in Table $I$. Ascending cholangitis was diagnosed and antibiotic therapy begun. Chloramphenicol had a clear effect, while gentamicin, kanamycin, cephaloridine, carbenicillin, nalidixic acid, lincomycin, and ampicillin seemed to have none. After several courses of chloramphenicol he is now asymptomatic, with normal serum bilirubin, serum protein, and $\gamma$-globulin levels.

Case 5. A male infant was admitted at 2 months with the diagnosis of biliary atresia. Laparotomy at $2 \frac{1}{2}$ months revealed absence of the hepatic ducts and distal choledochus. The proximal choledochus was cystic. The gallbladder was small. The liver was dark brown in colour.

After resection of the gallbladder and choledochus cyst the first-stage operation of hepatic portojejunostomy was performed leaving a segment of the jejunum for bile drainage $60 \mathrm{~cm}$ long. Bile excretion was excellent and jaundice subsided. The pre-operative serum bilirubin of $14.7 \mathrm{mg} / 100 \mathrm{ml}$ was reduced to $1.3 \mathrm{mg} / 100 \mathrm{ml} 2$ months after operation, when the second-stage operation was carried out.

Blood chemistry at 5 months of age ( $2 \frac{1}{2}$ months after operation) was cephalin-cholesterol flocculation negative, thymol turbidity $4 \cdot 6$ units, zinc sulphate $5 \cdot 3$ units; total bilirubin $<1.0 \mathrm{mg} / 100 \mathrm{ml}$, alkaline phosphatase 74. 0 Kind-King units, SGOT 48 units, SGPT 28 units, SLDH 364 units, total cholesterol $191 \mathrm{mg} / 100 \mathrm{ml}$, and total protein $6.9 \mathrm{~g} / 100 \mathrm{ml}$.

Postoperative course was without incident. 2 months after the second-stage operation, however, fever suddenly developed, with slight jaundice (Table I). A diagnosis of ascending cholangitis was made and antibiotic therapy was instituted. Gentamicin had a clear effect and two courses were given during 5 weeks. Since then he has been asymptomatic. At 19 months abdominal examination showed no ascites, and the liver was $3 \mathrm{~cm}$ below costal margin. Investigations: cephalincholesterol flocculation negative, thymol turbidity $2 \cdot 2$ units, zinc sulphate $4 \cdot 5$ units, alkaline phosphatase $27 \cdot 3$ Kind-King units, SGOT 26 units, SGPT 22 units, total cholesterol $139 \mathrm{mg} / 100 \mathrm{ml}$, and total protein $7 \cdot 1 \mathrm{~g} / 100$ $\mathrm{ml}$ with $3.8 \mathrm{~g} / 100 \mathrm{ml}$ albumin and $3.3 \mathrm{~g} / 100 \mathrm{ml}$ globulin.

Case 6. A female infant of $1 \frac{1}{2}$ months was referred to this hospital with the diagnosis of biliary atresia. Laparotomy at 2 months revealed a greenish firm liver, a choledochus cyst, and a small gallbladder. The hepatic ducts were patent. The distal choledochus was rudimentary. The gallbladder and choledochus cyst contained colourless fluid. Hepaticojejunostomy with Roux-en-Y anastomosis was performed leaving a segment of the jejunum for bile drainage $45 \mathrm{~cm}$ long.

Her postoperative course was uneventful. Bile excretion was good and jaundice disappeared 6 weeks after operation. Blood chemical studies at this stage showed the following: thymol turbidity 2.0 units, zinc sulphate $1 \cdot 3$ units, alkaline phosphatase $40 \cdot 0$ Kind-King units, SGOT 69 units, SGPT 41 units, total cholesterol $144 \mathrm{mg} / 100 \mathrm{ml}$, and total protein $6.0 \mathrm{~g} / 100 \mathrm{ml}$ with 3.6 $\mathrm{g} / 100 \mathrm{ml}$ albumin and $2.4 \mathrm{~g} / 100 \mathrm{ml}$ globulin.

Fever and slight jaundice developed $3 \frac{1}{2}$ months after operation. The abdomen was distended but with no detectable ascites. The liver was palpable $8.5 \mathrm{~cm}$, and the spleen $3.5 \mathrm{~cm}$. Laboratory findings at this stage are shown in Table I. A combination of intermittent oral cephalexin and kanamycin led to improvement of her condition.

Case 7. A female infant of 3 weeks of age was referred with the diagnosis of biliary atresia. Laparotomy at 1 month revealed a rudimentary hepatic and common duct. The gallbladder was small but patent. The first-stage operation of hepatic portojejunostomy was performed, leaving a segment of the jejunum for bile drainage about $40 \mathrm{~cm}$ long. Bile excretion was good and jaundice was negligible at 2 months of age, when the second-stage operation was carried out. Blood chemistry at this stage showed cephalin-cholesterol flocculation $2+$, thymol turbidity $1 \cdot 1$ units, zinc sulphate 0.8 units, total bilirubin 1.19 $\mathrm{mg} / 100 \mathrm{ml}$, alkaline phosphatase $51.0 \mathrm{Kind}-\mathrm{King}$ units, SGOT 75 units, SGPT 58 units, total cholesterol 200 $\mathrm{mg} / 100 \mathrm{ml}$, and total protein $6 \cdot 2 \mathrm{~g} / 100 \mathrm{ml}$.

Three months after the second-stage operation she developed attacks of fever with abdominal distension; intramuscular cephaloridine was given. The stools became acholic and obstructive jaundice of moderate degree reappeared, which deepened during the febrile periods (Table I).

Attacks of fever continued over a period of 8 months, but then disappeared; since then she has complained of severe pruritus and has developed generalized xanthomata. Blood chemistry at this stage was zinc sulphate 15.6 units, total bilirubin $9.9 \mathrm{mg} / 100 \mathrm{ml}$, alkaline phosphatase 91.5 Kind-King units, SGOT 181 units, SGPT 124 units, and total cholesterol 1290 $\mathrm{mg} / 100 \mathrm{ml}$.

Oral cholestyramine (a bile-acid-sequestering resin) 4 to $6 \mathrm{~g}$ daily, was instituted at the age of 18 months; the xanthomata gradually decreased and the pruritus was much improved. Serum total cholesterol and bilirubin was reduced to $272 \mathrm{mg} / 100 \mathrm{ml}$ and $4.5 \mathrm{mg} / 100 \mathrm{ml}$, respectively, at $3 \frac{1}{2}$ years.

Case 8. A female infant of 2 months was admitted with the diagnosis of biliary atresia. Laparotomy at $3 \frac{1}{2}$ months revealed absence of the hepatic ducts, a small gallbladder, and rudimentary common duct. The firststage hepatic portojejunostomy was carried out, leaving a segment of the jejunum for bile drainage $40 \mathrm{~cm}$ long. 
Bile excretion was good and serum total bilirubin level fell from the pre-operative level of $12.8 \mathrm{mg} / 100 \mathrm{ml}$ to $2.5 \mathrm{mg} / 100 \mathrm{ml} 8$ weeks after operation. The second operation was performed at 5 months of age, and she was discharged home at 6 months. Laboratory findings at this stage showed $\mathrm{Hb} 13.2 \mathrm{~g} / 100 \mathrm{ml}$, white blood cell count $8800 / \mathrm{mm}^{3}$, thymol turbidity 1.6 units, zinc sulphate 1.3 units, serum total bilirubin $2.4 \mathrm{mg} / 100 \mathrm{ml}$, serum alkaline phosphatase $47 \cdot 1$ Kind-King units, SGOT 56 units, SGPT 54 units, and serum total cholesterol $191 \mathrm{mg} / 100 \mathrm{ml}$.

She appeared quite well, except for some prominence of the abdomen, for the next 5 months. Fever then developed, with slight jaundice and pruritus. Chloramphenicol proved effective and several courses were given orally. Attacks of fever, however, still continued during the following 3 years. Xanthomata developed at 13 years. Cholestyramine, $2 \mathrm{~g}$ daily, has been given for pruritus and xanthomatosis from 1 year. Jaundice has occurred only when fever has been present. Laboratory findings during the febrile period are given in Table I.

\section{Results}

Incidence of ascending cholangitis after surgery. Out of 17 successfully repaired cases who had shown satisfactory bile excretion after surgery and who had no jaundice, $8(47 \%)$ developed the syndrome of ascending cholangitis.

4 of these 8 cases received a two-stage procedure of hepatic portojejunostomy, 2 received a one-stage operation, 1 had a choledochojejunostomy, and 1 a hepaticojejunostomy. Incidence of ascending cholangitis among successfully repaired cases in each operative group was as follows: one-stage operation $2 / 4(50 \%)$, two-stage operation $4 / 10$
(40\%), and choledocho- or hepaticojejunostomy $2 / 3$ $(67 \%)$.

Three of 8 cases died from the disease. Necropsy was carried out in 2 and revealed multiple cholangitic abscesses.

By contrast, none developed cholangitis in the surgically uncorrected group, sugesting that patency of the intra- and extrahepatic biliary passages was essential for the development of the disease.

Clinical features of ascending cholangitis (Table II). Acute ascending cholangitis after hepatic portoenterostomy was characterized by repeated attacks of high remittent fever, abdominal distension, hepatosplenomegaly, and reappearance of obstructive jaundice of slight to severe degree. The onset of the symptoms was $3 \frac{1}{2}$ to $8 \frac{1}{2}$ months after operation, with an average of 5.6 months. In fulminating cases there was no response to any antibiotic, with formation of multiple cholangitic abscesses of the liver (Cases 1 and 2). In the prolonged type of case, severe pruritus and xanthomata developed. Relapse was common (Cases 7 and 8).

Laboratory findings in ascending cholangitis (Table I). Laboratory studies showed anaemia, leucocytosis with shift to left, marked rise of ESR, and positive CRP. Blood chemistry showed mild to moderate jaundice of obstructive type. Serum transaminases were normal to slightly raised. Serum alkaline phosphatase levels were moderately raised. Serum total cholesterol levels were normal

TABLE II

Clinical findings of 8 cases of cholangitis after hepatic portojejunostomy

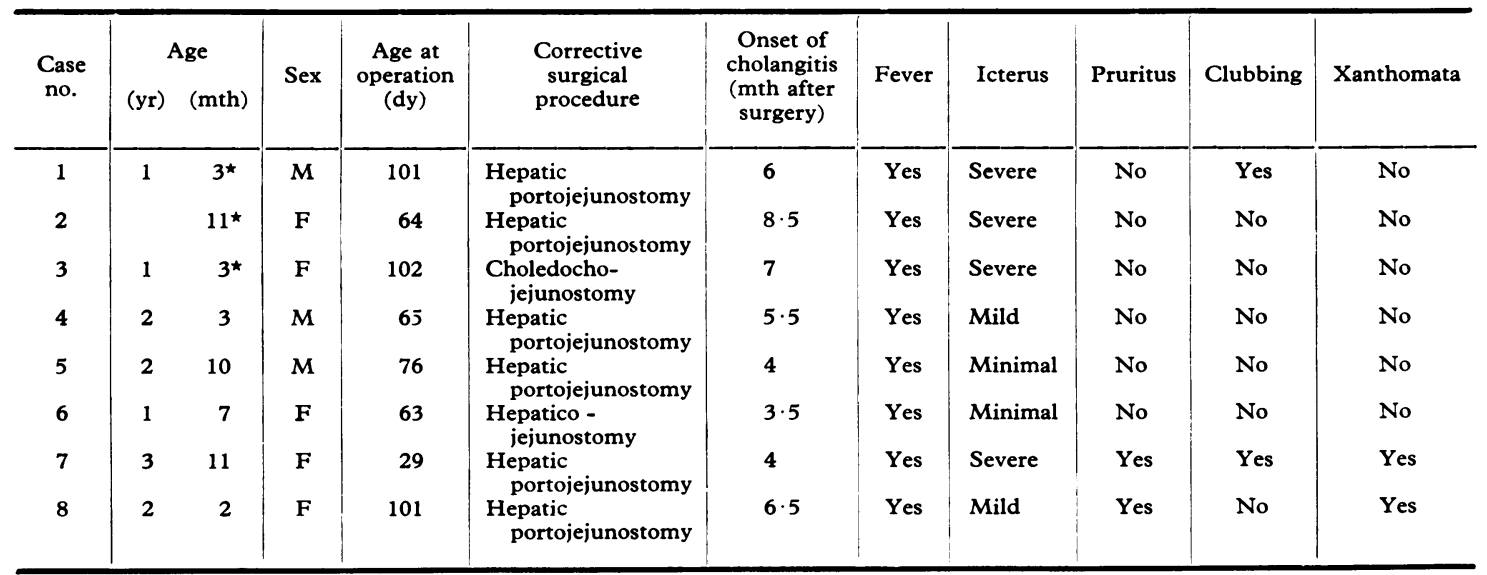

$\star$ Age at death. 
in the acute form, but raised in the prolonged cases. These findings were in agreement with the laboratory features of cholangitis reported by Wissmer (1965) and Matzander (1972). Serum albumin was reduced in the acute type, but normal in the prolonged cases. $\gamma$-Globulin was increased. Blood cultures carried out in 5 cases were negative. Echography of the abdomen showed no cystic pattern suggestive of a hepatic abscess.

\section{Discussion}

In the present series, after operation, excellent bile flow was observed in 13 cases out of 55 (24\%). These figures are obviously superior to those of Thaler and Gellis (1968) who reported that only 3 of 135 cases $(2 \%)$ of biliary atresia were successfully repaired during a 10-year period. Patients with atresia or agenesis of the hepatic ducts, not previously thought to be amenable to operation, may benefit from hepatic portojejunostomy if there is a true continuity of the intrahepatic biliary system.

It appeared obvious from the present series that the earlier the operation the better the results, so that operation should not be delayed, despite the difficulty of differentiating this condition from neonatal hepatitis (Redo, 1954; Schnug, 1958; Rickham and Lee, 1964).

The successful repair of biliary atresia, however, has given rise to a serious complication, ascending cholangitis. The complication was critical to determine the prognosis of the patients because some of the patients, who had shown excellent bile excretion after operation and had been symptom free, died of the disease.

Ascending cholangitis usually results from biliary stasis, as urinary tract infections result from urinary stasis. Necropsy examinations of Cases 1 and 2 in the present series, however, showed that the anastomosis between jejunum and porta hepatis was wide open. Ascending cholangitis reported here affected the patients in whom the biliary passages had been surgically repaired, and 'excellent' bile excretion had led to decrease in jaundice. It never occurred in the surgically uncorrected patients. However, 'excellent' bile excretion after hepatic portojejunostomy for biliary atresia was never as good as in adults after similar drainage of bile ducts into Roux-en-Y loops of the jejunum. The intrahepatic bile ducts were usually very narrow, even in the cases of extrahepatic biliary atresia. Furthermore, cirrhosis of the liver developing in this condition might contribute to narrowing the intrahepatic bile ducts. When the hepatic duct or the mass of the prevascular connective tissue of the hepatoduodenal ligament was cut as close as possible to the liver at operation, there were usually no wide openings of the intrahepatic bile ducts, but tiny greenish spots of less than $1.0 \mathrm{~mm}$ diameter were seen in some cases. Bile excretion was much decreased after hepatic portojejunostomy for biliary atresia compared with that seen in adults with a similar operation, and bile flow was very slow, though the anastomosis between jejunum and porta hepatis was wide open. On the other hand, in the surgically uncorrected patients bile excretion was absent and no anatomical connexions were found between the jejunum and the intrahepatic bile ducts at necropsy. On the basis of these findings cholangitis of this type occurred only in the patients with 'excellent' bile oozing, and never in the surgically uncorrected cases.

In the acute fulminating cases, who showed no response to any antibiotic agent, multiple abscesses of the liver were formed and the patients died from the lesions. The prolonged cases developed pruritus and xanthomata.

Causative organisms grown from the abscesses of the liver were intestinal flora: Esch. coli, klebsiella, Pr. mirabilis, Strep. mucosus, etc. It is reasonable to conclude that this cholangitis was of the ascending type.

In the present series chloramphenicol was effective in 2 cases, gentamicin in 1, cephaloridine in 1 , and oral cephalexin plus kanamycin in 1.3 patients did not respond to any agent and died. Effectiveness of the antibiotic drugs seemed to be dependent on the extent of the disease, because the causative organisms in Cases 1 and 2 were shown to be sensitive in vitro to some of the drugs used.

The disease developed $3 \frac{1}{2}$ to $8 \frac{1}{2}$ months after operation and was never observed after the age of 12 months in the present series. It is therefore necessary to treat patients with antibiotics for at least 10 postoperative months to prevent ascending infection. Because long-term antibiotic therapy may be harmful, it is advisable to administer antibiotics intermittently. For example, patients should be treated for 4 days of each week and receive no antibiotics on the subsequent 3 days. We are now studying the efficacy of long-term prophylactic intermittent antibiotic therapy.

We thank Drs. Shigenori Sawaguchi, Hiroshi Akiyama, Takashi Hori, and Takatoshi Kitamura, Department of Surgery, National Children's Hospital of Tokyo, for their helpful advice and guidance.

\section{REFERENCES}

Gerrish, E. W., and Cole, J. W. (1951). Surgical jaundice in infants and children. Archives of Surgery, 63, 529.

Gross, R. E. (1953). The Surgery of Infancy and Childhood, p. 508. Saunders, Philadelphia. 


\section{Ascending cholangitis after successful surgical repair of biliary atresia}

Holmes, J. B. (1916). Congenital obliteration of the bile ducts; diagnosis and suggestions for treatment. American fournal of Diseases of Children, 11, 405.

Kasai, M., Kimura, S., Asakura, Y., Suzuki, H., Taira, Y., and Ohashi, E. (1968). Surgical treatment of biliary atresia. fournal of Pediatric Surgery, 3, 665.

Kasai, M., Kimura, S., Wagatsuma, M., and Suzuki, H. (1963). Die chirurgische Behandlungen der angeborenen Missbildungen des Gallengangs. Therapiewoche, 12, 710.

Longmire, W. P., Jr., and Sanford, M. C. (1948). Intrahepatic cholangiojejunostomy with partial hepatectomy for biliary obstruction. Surgery, 24, 264.

Longmire, W. P., Jr., and Sanford, M. C. (1949). Intrahepatic cholangiojejunostomy for biliary obstruction-further studies. Annals of Surgery, 130, 455.

Matzander, U. (1972). Leberabscess und Cholangitis. Chirurg, 43, 364.

Moore, T. C. (1953). Congenital atresia of the extrahepatic bile ducts. Report of 31 proved cases. Surgery, Gynecology and Obstetrics, 96, 215.

Redo, S. F. (1954). Congenital atresia of extrahepatic bile ducts. Archives of Surgery, 69, 886.

Rickham, P. P., and Lee, E. Y. C. (1964). Neonatal jaundice: surgical aspects. Clinical Pediatrics, 3, 197.

Sawaguchi, S., Akiyama, H., Hori, T., Ishii, K., and Kitamura, T. (1972). Surgical treatment of congenital biliary atresia: hepatic porto-jejunostomy. Proceedings of the 5th Annual Meeting of the Pacific Association of Pediatric Surgeons, June, 1972, Tokyo.

Sawaguchi, S., Nakajo, T., Hori, T., Ohta, Y., and Yoshinari, M. (1971). Two stage operation for congenital biliary atresia: a temporary external biliary fistula with a jejunal segment. Proceedings of the 4th Annual Meeting of the Pacific Association of Pediatric Surgeons, May, 1971, Vancouver and Harrison Hot Springs.

Schnug, G. E. (1958). Importance of early operation in congenital atresia of the extrahepatic bile ducts. Report of ten proved cases. Annals of Surgery, 148, 931.

Silverberg, M., Craig, J., and Gellis, S. S. (1960). Problems in the diagnosis of biliary atresia. A review and consideration of histological criteria. American fournal of Diseases of Children, $99,574$.

Sterling, J. A. (1957). Total bile duct atresia. Pediatric Clinics of North America, 4, 769.

Sterling, J. A., and Lowenburg, H. (1962). Observations of infants with hepatic duct atresia and use of artificial duct prosthesis. Pediatric Clinics of North America, 9, 485.

Thaler, M. M., and Gellis, S. S. (1968). Studies in neonatal hepatitis and biliary atresia. III. Progression and regression of cirrhosis in biliary atresia. American fournal of Diseases of Children, 116, 271.

Wissmer, B. (1965). Cholangitis. In Gastroenterology, 2nd ed., Vol. III, p. 827. Ed. by H. L. Bockus. Saunders, Philadelphia and London.

Correspondence to Dr. Akio Kobayashi, Department of Paediatrics, National Children's Hospital, Taishido 3-35-31, Setagaya-ku, Tokyo, Japan. 